\title{
Skills shortages in the 90s : EU skills shortages update project synthesis report
}

Citation for published version (APA):

Oosterhuis, J. A. J. J., \& van der Velden, R. K. W. (1994). Skills shortages in the 90s : EU skills shortages update project synthesis report. Researchcentrum voor Onderwijs en Arbeidsmarkt, Faculteit der Economische Wetenschappen. ROA Reports No. 8E https://doi.org/10.26481/umarep.199408E

Document status and date:

Published: 01/01/1994

DOI:

10.26481/umarep.199408E

Document Version:

Publisher's PDF, also known as Version of record

\section{Please check the document version of this publication:}

- A submitted manuscript is the version of the article upon submission and before peer-review. There can be important differences between the submitted version and the official published version of record.

People interested in the research are advised to contact the author for the final version of the publication, or visit the DOI to the publisher's website.

- The final author version and the galley proof are versions of the publication after peer review.

- The final published version features the final layout of the paper including the volume, issue and page numbers.

Link to publication

\footnotetext{
General rights rights.

- You may freely distribute the URL identifying the publication in the public portal. please follow below link for the End User Agreement:

www.umlib.nl/taverne-license

Take down policy

If you believe that this document breaches copyright please contact us at:

repository@maastrichtuniversity.nl

providing details and we will investigate your claim.
}

Copyright and moral rights for the publications made accessible in the public portal are retained by the authors and/or other copyright owners and it is a condition of accessing publications that users recognise and abide by the legal requirements associated with these

- Users may download and print one copy of any publication from the public portal for the purpose of private study or research.

- You may not further distribute the material or use it for any profit-making activity or commercial gain

If the publication is distributed under the terms of Article $25 \mathrm{fa}$ of the Dutch Copyright Act, indicated by the "Taverne" license above, 
SKILLS SHORTAGES IN THE 90s

EU Skills Shortages Update Project

Synthesis Report

ROA-R-1994/8E

This project was financially supported by the European Commission,

Task Force Human Resources, Education, Training and Youth

J.A.J.J. Oosterhuis

R.K.W. van der Velden

RESEARCH CENTRE FOR EDUCATION AND THE LABOUR MARKET

Faculty of Economics and Business Administration

University of Limburg

Maastricht, August 1994 


\section{CIP GEGEVENS KONINKLIJKE BIBLIOTHEEK, DEN HAAG}

Oosterhuis J.A.J.J.

Skills shortages in the 90s: EU skills shortages update project: synthesis report/J.A.J.J. Oosterhuis, R.K.W. van der Velden. - Maastricht: Research Centre for Education and the Labour Market, Faculty of Economics and Business Administration, University of Limburg. - ([Report] / Research Centre for Education and the Labour Market, ISSN 0922-8098 ; ROA-R-1994/8E)

ISBN 90-5321-136-5

Trefw.: werkgelegenheid ; Europa. 
CONTENTS

Page

EXECUTIVE SUMMARY

i

1. INTRODUCTION 1

2. OBJECTIVES 3

3. REGIONAL PROFILES 5

3.1. Greater Copenhagen Area (Denmark) 5

3.2. Anglia (United Kingdom) 6

3.3. Weser-Ems Region (Germany)

3.4. Mid-West of Ireland 7

3.5. Campania (Italy) 8

4. METHODOLOGIES 9

4.1. Greater Copenhagen Area (Denmark) 9

4.2. Anglia (United Kingdom) 9

4.3. Weser-Ems Region (Germany) 10

4.4. Mid-West of Ireland 10

4.5. Campania (Italy) 11

5. REGIONAL SUMMARIES AND COMPARISON WITH THE 1991 SITUATION 12

5.1. Greater Copenhagen Area (Denmark) 12

5.2. Anglia (United Kingdom) 14

5.3. Weser-Ems Region (Germany) 16

5.4. Mid-West of Ireland 19

5.5. Campania (Italy) 20

6. SUMMARY 22

6.1. Skills shortages $\quad 22$

6.2. Training 22

7. DISCUSSION AND GENERAL RECOMMENDATIONS 24

8. MONITORING SKILLS SHORTAGES IN THE FUTURE: THE SKILLS BAROMETER 26

8.1. Introduction 26

$\begin{array}{ll}\text { 8.2. Measuring skills shortages } & 27\end{array}$

8.3. Cross-sectional or panel design? 27

8.4. Sample design 28

8.5. Data collection 28

$\begin{array}{ll}\text { APPENDIX: PARTICIPATING REGIONS } & 30\end{array}$ 


\section{EXECUTIVE SUMMARY}

* This reports draws together the main conclusions of the third phase in the European Union Skills Shortages Project, commissioned by the Task Force Human Resources. It involves five regions - the Greater Copenhagen Area, Denmark; Anglia, United Kingdom; Weser Ems, Germany; the Mid-West of Ireland; and Campania, Italy - in which a survey was carried out to update the information gathered in the first two phases.

* Between 1991 and 1994, all regions have faced a general reduction in quantitative and qualitative skills shortages. This is mainly due to the recession, which decreased the labour demand and increased the general skills levels of the unemployed labour force.

* Quantitative skills shortages are generally limited to only a few categories of personnel. The specific categories of labour shortages vary to a large extent among regions.

* Qualitative skills shortages are mainly manifested in the need for multi-skilled personnel. In addition, combinations of technical and managerial skills have been in large demand.

* It is expected that new skills shortages will arise in an economic upswing.

* Generally, training expenses have not decreased during the last recession. The opinion is however, that training primarily goes to certain groups (higher level management), whereas other groups participate relatively less in training.

* Few firms have structured long term training policies.

* Quality of the training provided is the first criterion in choosing an external training provider, training costs come in fourth. The results of training, however, are hardly ever assessed in terms of a cost and benefit analysis. 


\section{INTRODUCTION}

This reports draws together the main conclusions of the third phase in the European Union Skills Shortages Project, commissioned by the Task Force Human Resources.

Phase I of the Skills Shortages Project involved four leading agencies in regions of the European Union chosen for their divergent characteristics in a survey of companies and training organisations views of the skills needs in the labour market. These four regions were Thames Valley, United Kingdom (TARGET); Dublin, Ireland (Dublin Technology Partnership); Western Greece, Greece (Ursa-Net); and Nord - Pas de Calais, France (Comett Nord - Pas de Calais), as can also be seen from figure 1. After a conference, the results of the final reports of the regions were compiled in one synthesis report.

Phase II of the project involved the four original lead agencies in the identifications of five or six partner regions (chosen for the similarity of their characteristics with their lead regions) who would then carry out the same project in their own region. The partner regions carried out the project based on the directions given and the methodology used by their lead region. The findings of the partner regions were commented and examined in a conference coordinated by the respective lead agencies. In sum then, four compilation reports were drawn up. A total of 26 regions participated in this phase II. After a conference a final synthesis report based on the 26 final reports was compiled in August 1991 (TARGET, 1991).

Phase III of the Skills Shortages Project was set up in 1993. It involves five regions (and one region charged with the coordination) in which a survey was carried out to update the information gathered in the first two phases. The participating regions are: the Greater Copenhagen Area, Denmark (Danish Technological Institute); Anglia, United Kingdom (Artiste Limited); Weser Ems, Germany (Comett Partnershaft W.E.R); the Mid-West of Ireland (European Liason Centre); and Campania, Italy (Comett Tec Train). The Researchcentre for Education and the Labour Market - located in the region of Limburg, the Netherlands - was charged with the coordination of the Skills Shortages Update.

As can be seen from figure 1, the five selected regions participating in the Update were all either former partner region to the TARGET lead region or former partner to the Ursa-Net region. This has been an advantageous feature since these two groups of regions (TARGET and Ursa-Net) have used a case study, company centred approach, focusing on company-specific findings, whereas the other two groups of regions have used a sectoral commentary approach resulting in regional and sectoral overviews (Dublin Technology Partnership and Comett Nord - Pas de Calais). Therefore, the angle of incidence and the resulting methodologies used in the TARGET and Ursa-Net group were fairly comparable.

In the launch meeting of the Skills Shortages Update in December 1993, the regions have agreed on using the same methodology (with some small adjustments) as has been used in the second phase. This makes it possible to compare the present situation within a region to the situation three years ago. There is one exception, however; the research done in phase II by the Danish Technological Institute regarding the skills shortages in the Greater Copenhagen Area, differed to large extent from the other regions. The Greater Copenhagen Area has adopted the approach of the other regions in the Update project to facilitate inter-regional comparability.

Each region has written a report containing the results of their survey (see Appendix). The results of these reports were discussed and commented in a final meeting in Osnabrück in April 1994. The reports of the regions and the discussion of the meeting have resulted in this final synthesis report. 
This figure gives the regions participating in the various phases of the Skills Shortages Project. Phase I indicates the four lead regions. Each leading regions has chosen five or six partner regions; these are mentioned vertically under the name of the lead regions. The Greater Copenhagen Area and Anglia for example were partners of the Thames Valley region in Phase II. Phase three gives the participating regions in the Skills Shortages Update in $1993-1994$.

Figure 1. The EU Skills Shortages Project

\begin{tabular}{|c|c|c|c|}
\hline \multicolumn{4}{|c|}{ Phase l; lead regions } \\
\hline $\begin{array}{l}\text { Thames Valley } \\
\text { United Kingdom } \\
\text { (TARGET) }\end{array}$ & $\begin{array}{l}\text { Dublin } \\
\text { Ireland } \\
\text { (Dublin Technology } \\
\text { Partnership) }\end{array}$ & $\begin{array}{l}\text { Western Greece } \\
\text { Greece } \\
\text { (Ursa-Net) }\end{array}$ & $\begin{array}{l}\text { Nord-Pas de Calais } \\
\text { France } \\
\text { (Comett Nord-Pas de } \\
\text { Calais) }\end{array}$ \\
\hline \multicolumn{4}{|c|}{ Phase II; partner regions } \\
\hline $\begin{array}{l}\text { Greater Copenhagen Area } \\
\text { Denmark }\end{array}$ & $\begin{array}{l}\text { Limburg } \\
\text { The Netherlands }\end{array}$ & $\begin{array}{l}\text { Central Portugal } \\
\text { Portugal }\end{array}$ & $\begin{array}{l}\text { Mid-Glamorgan } \\
\text { United Kingdom }\end{array}$ \\
\hline $\begin{array}{l}\text { Palermo } \\
\text { Italy }\end{array}$ & $\begin{array}{l}\text { Mid-West of Ireland } \\
\text { Ireland }\end{array}$ & $\begin{array}{l}\text { Bremen } \\
\text { Germany }\end{array}$ & $\begin{array}{l}\text { Pays de la Loire } \\
\text { France }\end{array}$ \\
\hline $\begin{array}{l}\text { Setubal } \\
\text { Portugal }\end{array}$ & $\begin{array}{l}\text { Campania } \\
\text { Italy }\end{array}$ & $\begin{array}{l}\text { Guipuzcoa } \\
\text { Spain }\end{array}$ & $\begin{array}{l}\text { Berlin } \\
\text { Germany }\end{array}$ \\
\hline $\begin{array}{l}\text { Eastern Macedonia / Thrace } \\
\text { Greece }\end{array}$ & $\begin{array}{l}\text { Hainaut } \\
\text { Belgium }\end{array}$ & $\begin{array}{l}\text { Weser Ems } \\
\text { Germany }\end{array}$ & $\begin{array}{l}\text { Castilla/Leon } \\
\text { Spain }\end{array}$ \\
\hline $\begin{array}{l}\text { Valencian } \\
\text { Spain }\end{array}$ & $\begin{array}{l}\text { Liguria } \\
\text { Italy }\end{array}$ & $\begin{array}{l}\text { Sachsen-Anhalt } \\
\text { Germany }\end{array}$ & \\
\hline \multicolumn{4}{|c|}{ Phase III; update regions } \\
\hline $\begin{array}{l}\text { Greater Copenhagen } \\
\text { Area } \\
\text { Denmark }\end{array}$ & $\begin{array}{l}\text { Limburg } \\
\text { The Netherlands } \\
\text { (Coordination of the } \\
\text { Update) }\end{array}$ & \multicolumn{2}{|c|}{$\begin{array}{l}\text { Mid-West of Ireland } \\
\text { Ireland }\end{array}$} \\
\hline $\begin{array}{l}\text { Anglia } \\
\text { United Kingdom }\end{array}$ & & \multirow{2}{*}{\multicolumn{2}{|c|}{$\begin{array}{l}\text { Campania } \\
\text { Italy }\end{array}$}} \\
\hline $\begin{array}{l}\text { Weser Ems } \\
\text { Germany }\end{array}$ & & & \\
\hline
\end{tabular}

Source: "EC Skills Shortages Project, 1990/1991. Final Synthesis Report" by TARGET. 


\section{OBJECTIVES}

The main objective of the regional studies is to update the information regarding skills shortages gathered in 1991. The emphasis is on intra-regional comparability, i.e. comparing the situation of 1991 with the present (1994) situation within a region. Interregional comparability will also be of major importance.

Skills shortages is a term used to describe that the supply of skills does not equal the demand for skills. It can refer to quantitative as well as qualitative skills shortages. The former means that there is a numerical shortage of people who are qualified for a certain job. Qualitative skills shortages on the other hand refer to the problem that either new entrants or already working employees (or both) do not have the skills required. Quantitative skills shortages manifest themselves in hard-to-fill vacancies. Qualitative skills shortages refer to gaps between specific qualification required in a job and the skills of the employee. Both quantitative and qualitative skills shortages will be addressed in the reports.

\section{Skills Shortages}

Skills shortages occur when the demand for skills does not equal the supply of skills.

* Quantitative skills shortages point to numerical shortages of people who are qualified for a certain job.

* Qualitative skills shortages refer to the problem that either new entrants or already working employees (or both) do not have the skills required to do a certain job.

In order to be able to take corrective actions to prevent the emergence of skills shortages, future expectations regarding the skills profile will be addressed as well. Finally, descriptions of examples of best practice can be found in the regional reports, for they are very useful in the identifications of possible corrective actions.

Based on the objective of updating the 1991 information regarding skills shortages, each region has defined its own terms of reference, guided by the findings of their previous report. Therefore, the emphases in the reports are slightly different.

For example, the emphasis in the survey of the region of Campania, Italy, lies primarily in the area of examining the role and effectiveness of training and identifying employment and training related problems together with emphasis on new labour market shortages.

The survey held in the Greater Copenhagen Area, on the other hand, focuses on the question whether or not any skills shortages can de detected, since the 1991 survey indicated that there were hardly any skills shortages in this region. The larger part of the survey concentrated at identifying corrective actions aimed at preventing and solving possible skills shortages.

The Anglia region also aims at updating the 1991-information. Therefore, it concentrates in its survey on the description of the current predominant skills shortages, and the identification of its causes. For instance, do such shortages reflect unfilled job vacancies arising from increased production or the establishment of new-start up companies as the UK economy begins to recover. Further, to what extent do these skills shortages reflect a lack of expertise and training in the application of new technologies which has created new vacancies or a requirement for additional training of existing staff. 
$-4-$

The survey of Ireland focused mainly on the possibility to compare the 1991 information with the newly gathered data concerning skills shortages.

Finally, the Weser Ems region survey focuses on the summary of the profile of the quantitatively and qualitatively of present skills shortages in comparison with the 1991-results, the analysis of the potential differences, the outline of future expectations, and the description of examples of best practice and possible corrective actions.

The aims of this synthesis report are as follows. First, the findings of the five reports of regions involved in the Skills Shortages Update will be synthesized. Secondly, these findings and their derived conclusions will be compared with the results obtained in the first two phases of the Skills Shortages Project. Finally, the possibilities for future monitoring of skills shortages will be examined. 


\section{REGIONAL PROFILES}

In the following, a summary of the regional profile of the five regions will be given. The first three regions, the Greater Copenhagen Area, Anglia and the Weser Ems Region (the former TARGET partners) may be generally characterised as industrially developed, diversified and dynamic. In the research of 1991 they all showed a trend to grow in the tertiary sector, enjoyed relatively low unemployment and their traditional labour sources tended to be fully exploited. They are SME dominated, with no single industry sector preeminent. These regions now suffer from the adverse effects of the recession, which have lessened their growth, but the degree in which the regions are affected varies. There are however signs of fragile economic recovery.

The last two regions, former Ursa-Net partners Mid-West of Ireland and Campania, are peripheral EU regions, and in addition peripheral within their own countries, with a dominant role played by cities and urban developments in economic, labour and political arenas. SME's predominate throughout, especially in the traditional economic sectors. These regions are coastal regions with involvement in sea transport and tourism. All perceive themselves as starved from resources, facing serious time pressure if they are to catch up with the rest of the community. The present recession has deepened the economic problems of these regions.

\subsection{Greater Copenhagen Area (Denmark)}

The Greater Copenhagen Area (GCA) has a population of 1.2 million (1991) and a workforce of 625,000 (including employed as well as unemployed). $48 \%$ of the employed are women. The service sector is much more important than the manufacturing sector. $81 \%$ of those employed at enterprises in the area work in the private or public service sector leaving only $18 \%$ to work in manufacturing and building. $45 \%$ of the workforce does not have any formal education besides primary or lower secondary school, meaning that this group has not attended school after the age of 16 . Some persons of this group have participated in additional courses, but they may not be considered to have had formal education. The workforce of the GCA is better educated than the average in Denmark. Generally, men are better educated than women.

The number of persons in the workforce has decreased by 17,600 persons in the period from 1987 to 1990. The decrease was especially significant for men and for relatively older people. The workforce is getting older. This could have presented a problem since the young are better educated than the old people. Still the average level of education has increased in the period.

577,000 of the inhabitants were employed in 1991. The number of commuters to the area is 165,000 persons while 52,000 of the inhabitants worked outside the region. More inhabitants work in the public services while relatively fewer work in banking, insurance and business-to-business services. This is probably due to the different qualification needs - banking et cetera requires employees with higher education while the public sector contains a relatively larger number of jobs requiring no formal higher education. Commuters are relatively better educated than the inhabitants in general.

The region has lost a great number of jobs in the period since the last report was made based on 1987 and 1988 figures. In the years 1988 to $1991,40,759$ jobs were lost, equalling $6 \%$. The jobs were lost in all sectors. Contrary to the previous years, the service sector could no longer make up for the loss in the manufacturing sector. The job loss was much more severe in the central municipalities than in the suburbs. This is largely because big companies in the wholesale, transportation and banking, insurance \& business-to-business sectors moved to the suburbs. 
In 1991, the number of unemployed was 65,000 (counted as full-time unemployed). Since then the number has increased considerably $(+21 \%)$ and is now 78,750 (1993). Almost all groups are affected severely. Only nurses have no unemployment - only $0.3 \%$ did not have a job. This indicates possible recruitment problems. The share of persons without formal education is much higher among the unemployed and the long-term unemployed than in the workforce (and among the employed). The share of higher educated is much lower among the unemployed and the long-term unemployed than in the workforce - with the exception of the highest educated persons.

The demand for higher educated people is rising. This is reflected by the development in employment in the period 1987 to 1990 . During this period the job loss has been felt much more by semi-skilled than those with higher education. While the semi-skilled lost $12 \%$ of the jobs, skilled workers only lost $1 \%$ and the higher educated increased their employment - most significantly the highest educated increased their employment by $13 \%$. The distribution of the workforce by education has changed showing an increase in the educational level of the employed.

\subsection{Anglia (United Kingdom)}

The Anglia region is a large area of England to the North-East of London and comprising the counties of Norfolk, Suffolk, Essex, Cambridgeshire, Bedfordshire and Hertfordshire. The population of the region is 5.08 million or $8.9 \%$ of the total population of the UK.

The Region has a very dynamic economy which until mid-1990 had the highest rate of growth of all regions in the UK. The past economic recession in the UK has persisted longer than expected and has had a quick and marked effect upon the region with a significant reduction in the rate of growth. Many large employers have made redundancies and instituted periods of short-time working and there have been a number of failures of firms of all sizes.

In the last four months, there have been signs that the economy of the region is starting to begin a recovery, but these do not yet confirm that the region is coming out of recession. It is expected that the past economic downturn in the Anglia region is a temporary setback and that as the UK economy recovers, the economic growth of the region will return to its former high rate.

During the past three years, manufacturing activities have continued to decline. The former rapid growth of the service sector which was providing compensation in employment for the loss of jobs in the industrial sector, has slowed considerably or gone into decline. Comparison of the statistics for new firm formation and for firms going out of business shows a nett loss in 1992. It is estimated that 45,000 professional engineers, scientists and managers have been made redundant by larger companies. This represents a large body of highly qualified professional people.

The level of unemployment in the region has continued to rise since the last report on Skills Shortages in 1990-1991. This has eased staff recruitment problems with firms now reporting difficulties only in specialized areas. The total number of the total work labour force is estimated to have fallen by approximately 50,000 during the last three years to a new level of 2.55 million. The total number of people in employment in early 1991 was 1.934 million, at the end of 1991 it was 1.868 million. It is now estimated to have fallen to 1.808 million in 1993; which means a total drop of 126.000 compared to 1990 .

The Anglia region is well provided with academic training institutions and private training organisations. Effects of economic stringency and reduced or contained funding from central government have given increased impetus to the Universities and Colleges of Further Education to pursue programmes of 
continuing education aimed at employees at all levels.

\subsection{Weser-Ems Region (Germany)}

The region Weser-Ems counts 2.17 million inhabitants. It stretches about $100 \mathrm{~km}$ from the Dutch border in the west to the Weser river in the east. Eighty percent of the region is used for agricultural industry. The administrative centre is Oldenburg, the first runner up in the number of inhabitants after Osnabrück.

Factors that make the Weser Ems Region less attractive are as follows. First, road, train and air traffic infrastructure is partly underdeveloped. In addition, the average skills level dominates in this region. Further, there is a scarcity of available industrial estates, particularly in urban areas. Finally, the region lacks an image or has a bad image. More positive factors regarding this region are the low level of wages and salaries, the low level of rents and estate prices and regional leisure and living potential.

The region encounters severe problems in its economic development (agriculture, shipbuilding, steel and metal processing. Therefore, the number of unemployed has been well above the average in the "old" federal states. Only recently, young enterprises in the area of new technologies have emerged. The region shows a strong bias towards SME's. The participation in R\&D is below average.

The major regional issue is that new enterprises are needed which are able to draw on enough staff who are sufficiently familiar with the new technologies to stop the negative trend of recent years.

Due to limited time and resources an area within the Weser Ems Region was identified representative of the whole region. The desk and field research was conducted in this area; the Osnabrück - Emsland Grafschaft Bentheim area. It consists of urban and rural areas, declining and flourishing industries, a fair representation of professional organisation and other respective bodies, and a fairly typical structure of education and training.

\subsection{Mid-West of Ireland}

The Shannon Region or Mid-West Region of Ireland extends inwards from the central western seaboard of Ireland, straddling the Shannon river and estuary. The region includes the five counties of Clare, Limerick, Tipperary (North Riding) South Offaly and North Kerry. It embraces the whole of one Regional Authority area (Mid West) and parts of two others (Midlands and South West). The Shannon region has a population of 310,000 , with a low population density by European standards of 32 inhabitants per square kilometre. A third of the regional population is concentrated in or around Limerick City. The strategic 'hub' of the region is formed by the three centres of Limerick, Shannon (with its airport, town and Industrial Zone, 20 kilometres from Limerick) and Ennis (40 kilometres).

The region currently faces both development problems and opportunities which can be summarised as follows. As one of Ireland's western regions, the area experiences the extremes of peripherality, coupled with high unemployment (19\%) and rural decline. The demand for jobs is enlarged by heavy dependence on agriculture ( $16 \%$ of the labour force) and large volume of school leavers $(6,000$ per annum) relative to the population. Infrastructural deficiencies are represented by several factors - obsolete roads infrastructure, need for improved effluent treatment, demands for improved water supply and other environmental infrastructure, e.g. waste disposal. Rural decline has been significant with heavy concentration of development in the region's core and population loss in rural areas.

The region's assets, on the other hand, include proximity to trade routes, air communications, a strong 
technological base and rural and marine tourism. The presence of the University of Limerick, and Regional Technical Colleges at Tralee and Limerick, provides a strong basis for an educated labour force. A record of employment growth has been established. Between 1987 and 1992, a net increase of $15 \%$ jobs in industry and $+56 \%$ in tourism was achieved. The regional tourist industry has a present growth rate of $6 \%$ per annum (1988 - 1992) and a projected growth rate of $10 \%$ per annum by 1999 . Recent investment by EU Structural funds has been effective in providing key infrastructure for industry, tourism and rural development. Finally, the Region is unique in Ireland in that it is covered by a regional development agency, Shannon Development.

The region has a workforce of 130,000 of which 105,000 are in the non-agricultural sectors. To meet the needs of counteracting agricultural job losses, absorbing labour force growth and reducing unemployment, this non-agricultural workforce must grow considerably. If a target of cutting unemployment by half by the end of the decade were adopted, then non-agricultural employment would have to grow by a nett 29,000 or about $30 \%$ over 6 years.

There are a number of training institutions in this region such as the University of Limerick, Plassey Management and Technology Centre and Regional Technical Colleges in Limerick and Tralee. Problems however arise in keeping the skilled labour force in the region; especially University qualified people tend be to very mobile and move overseas. In $1992,28 \%$ of the students graduating with primary or higher degrees found employment overseas.

\subsection{Campania (Italy)}

The region of Campania is divided into five provinces: Naples (the regional capital), Salerno, Caserta, Avellino and Benevento. The population of the region of Campania is 5.7 million, distributed on a total area of 13,595 square kilometres. Campania suffers from the effects of a very high birth rate. The share of young people (0-24 years) amounts up to $44 \%$ of the population. The unemployment is about $23 \%$. From the total number of unemployed, $80 \%$ is younger than 29 years old. In reality the problem is much more severe since there is little incentive to register as unemployed. Many young people choose to enrol in a university, hoping to increase their chances of getting a job in the future. There is a brain-drain from Campania to the northern parts of Italy as young graduates leave the region.

Of the employed, about $59 \%$ works in the (non-)commercial services sector, $16 \%$ in agriculture, the same percentage in industry and about $9 \%$ in construction. The main sectors are tourism and public investment. The service sector is developed through public work. New enterprises are heavily subsidized. Agriculture is not very developed; the productivity is low. The region does not allow large-scale agricultural activities due to its mountainous nature and extensive division of land into small parts.

The survey of 1991 showed that the tourist sector was very flourishing and highly developed. New research shows that the situation has changed drastically: this sector has turned into a problem sector. Tourists have become more demanding, and competition has increased. Further, there is lack of entrepreneurial mentality or service culture oriented towards preserving and improving the heritage and facilities and diversifying the supply in order to rationalize tourist flows and fixed costs.

The building sector was mainly occupied with building new buildings in 1991. Nowadays, more old buildings are being renovated. The emphasis has therefore changed from constructionist towards "renovationists". Finally, leather and tanning is currently growing as a result of export increases. 


\section{METHODOLOGIES}

Since the present survey was intended to update the information obtained in that of 1991, it was thought appropriate that the partners should use their previous methodologies and incorporate any refinements necessary to elicit the specific information required at this time. This included the strategy of requesting interviewees to comment on the previous responses and/or their earlier predictions regarding the issue of skills shortages. One exception however was made. The methodology used in the survey of 1991 in the Greater Copenhagen Area differed to a large extent from the methodologies used by the other regions in the Update. Using the same methodology again would make an inter-regional comparison hard. Therefore, the project design for this region has been changed during the process.

\subsection{Greater Copenhagen Area (Denmark)}

The study of the Danish Technological Institute is based on four sources; statistics, analysis, questionnaires from a sample of companies, and interviews with a sample of companies.

First, statistics were used to show changes in regional structures regarding unemployment and hereby identifying indicators of changes in supply and demand of skills. The statistics are based on the most recent material dating from 1991, except for unemployment figures dating from 1993.

Secondly, analysis made by the Secretariat of the Labour Market Council were used, accounting quantitative skills needs. These data are based on reports on vacancies in the public labour market administration which primarily deals with (semi-) skilled jobs.

Out of 500 companies in the whole of Denmark that received a questionnaire, 181 returned it. Further study showed that the material obtained by these 181 questionnaires is reliable considering the similarity in the structure of companies being sent a questionnaire and having returned it. Out of the 181 returned questionnaires, 46 were from companies within the Greater Copenhagen Area.

Finally, interviews were carried out with the owner or the manager of the company. The interviews centred on questions regarding the planning of human resource development, the education and training activities, recruitment problems and skills shortages and the fulfilling of needs and barriers. Any uncertainties resulting from the previously filled out postal questionnaire were discussed during the interview. Thorough resumes were made after the interview.

\subsection{Anglia (United Kingdom)}

As a first stage, an evaluation of the available statistics for the Anglia region was undertaken regarding the areas of economic activity and industrial employment, employment forecasts, unemployment rates and trends, business activity based on high-technology and the formation and failures of new and small firms. These data would give a satisfactory indicator on current employment plus business activity and the impact of advanced technology in the region.

Secondly, out of 67 companies that took part in the 1991-study, 42 were re-interviewed by three people; two of them already took part in the interview team of 1991. Interviews were conducted against a standard questionnaire which was very similar to the one used in the 1991-study. The interviews were aimed at gathering in-depth information about present skills shortages and the overall company approach to present and future skills needs. Care was taken that all six counties were reasonably represented in the choice of the 42-companies, and that the spread of industries and activities and size of companies would be as wide as possible. Still, due to the fact that the 1991-list of companies was used to select the 
46 companies, there is a bias towards large organisations, a predominance of engineering and manufacturing and some concentration in the areas surrounding Cambridge and Norwich.

After the round of interviews, a Regional Seminar was arranged, which was attended by 25 persons from organisations which were interviewed and a wider range of companies and individuals. The results of the discussion in the Seminar were incorporated in the data analysis.

\subsection{Weser-Ems Region (Germany)}

In order to compare the results of the 1991-survey, 60 companies that had participated in the previous study were re-contacted; 48 were prepared to take part again. The remaining twelve either ceased their activities, had been taken over or refused to cooperate in the survey. First of all the companies were contacted by phone; effort was made to interview the same person as in the 1991-survey. In 31 cases, the same person, who was either an executive or a personnel manager, was re-interviewed. At the beginning of the interview, the 1991-research report and the report of the European Commission "Skills for a Competitive and Cohesive Europe" was given to the interviewees; figures of the latter report regarding skills shortages formed the basis of the discussion.

The original questionnaire was used again in the Update survey as an interview guideline. It was felt that the meetings with enterprises should additionally be used for more issues related to the topic of skills shortages. The data obtained were both quantitative and qualitative.

The problem encountered in confronting the interviewee with the figures regarding the skills shortages, is that the interviewee tended to react in the first instance by denying the figures. Only after pushing the matter further, the overall issues regarding skills shortages were revealed. The opinion is that these issues would not have been revealed only by phone calls.

A word of warning relates to the interpretation of the technical terms used in the survey report. The terms used correspond to their usage within the German national environment and are not necessarily equal to the literal translation.

\subsection{Mid-West of Ireland}

First, a steering committee was formed in order to exploit the knowledge and expertise of a number of regional organisations. The members were consulted in the course of the survey and were also sent a draft copy of the report.

Further, the majority $(71 \%)$ of companies interviewed in the 1991-survey and selected from the principal regional industry sectors, were re-contacted. In sum, 51 companies in eleven sectors were interviewed. Initial telephone contact was made with prospective respondents who were then sent a letter giving the rationale of the survey and a summarized version of the questionnaire. In addition, a report generated from the 1991 survey was attached. All approached companies agreed to collaborate in-depth telephone or personal interviews.

The questionnaire designed for the survey was based on the original 1991-questionnaire, but focused more narrowly on skills shortages and training strategies. The respondents to the questionnaire varied depending company size and structure. In addition, ten key regional players were identified who would be able to supply an overview of the condition of industry in the region. 
The information was analyzed using a database to process the quantitative data and a key-word based analysis of the unquantifiable information garnered from the interviews.

\subsection{Campania (Italy)}

First, a bibliographical and documentary research was carried out. The aim of the research was to examine the social and economic characteristics of the region, the local labour market typology and the considered sectors specifications.

Further, 100 companies were selected; most of which had already taken part in the 1991-survey. In addition, 15 associations were contacted being representative for groups of enterprises. Out of the 100 companies that were selected, 51 agreed to cooperate either in filling out the questionnaires or giving interviews. Ten percent of the selected enterprises had ceased their activities,

Easy-to-read and quick-to-understand questionnaires were then distributed among enterprises. The questionnaire comprised various subjects such as general information, development policy emphasizing professional training, and skills shortages and the provisional situation. In addition, a follow up took place by contacting enterprises by telephone and fax in order to give them a further input on the initiative.

Finally, face-to-face interviews with representatives of 40 of the 100 enterprises were held, in order to garner in-depth information regarding the subjects of the questionnaire and to identify the problems encountered on personnel training. 


\section{REGIONAL SUMMARIES AND COMPARISON WITH THE 1991 SITUATION}

\subsection{Greater Copenhagen Area (Denmark)}

The survey in the Greater Copenhagen Area is based on four sources: statistics, analyses of the Secretariat of the Labour Market Council, questionnaires and interviews with companies (see chapter 4; Methodologies).

The first source - statistics - does not provide any significant proof of the existence of skills shortages; this concerns a very rough way of measuring skills shortages, however. The educational level of the labour force in the GCA is higher than in the rest of the country and is rising. The skills level of the (longterm) unemployed is lower than that of the employed.

The second source concerns the quarterly reports of the Secretariat of the Labour Market Council. These reports are based on thorough examination of the whole labour market. After the year 1992, a problem concerning the labour market for nurses occurred. This development, however, is to a large extent due to political decisions. In addition, problems concerning the labour market of domestic help occurred. Further, the demand for bilingual (Danish-German) secretaries increased as a result of the increased export to Germany. Finally, shortages are found in areas of operators in the process industry and chauffeurs licensed to drive with dangerous goods.

All-in-all, little signs of skills shortages can be found in the quarterly reports. Therefore, questionnaires and interviews with companies were used to discover any additional skills shortages. These sources did not reveal other quantitative skills shortages beside the shortage of nurses. Concerning qualitative skills shortages, only from time to time companies had difficulty in finding employees with quite specific qualifications. In addition, employees sometimes have a problem in the recruitment of interested, motivated and flexible personnel. Finally, many companies feel that managers lack basic managerial skills.

In conclusion then, the problem of skills shortages seems to be of minor importance and tends to have no significant adverse consequences. The problems have not been as big as not to be resolved via continuing vocational training. This is the result of the high unemployment, the existence of a well-trained labour force, the commuting to the area, and the wide array of corrective actions.

\section{Corrective actions}

Corrective actions to prevent and solve skills shortages have proved to be very useful and effective. Corrective actions are taken at three levels; at national, regional and company level.

\section{National Level}

At national level, action towards quantitative and qualitative skills shortages is constituted by the labour market policy, conducted by the Ministry of Labour, and the policy conducted by the Ministry of Education. This policy is aimed at keeping up the qualifications of the labour force and at keeping the labour market flexible. In this respect, the labour market reform of 1994 and the national system of continuing vocational training can be mentioned.

In January 1994, the labour market reform was implemented aimed at a more flexible labour market and preventing skills shortages, thereby reducing unemployment in the long run. The two main elements of the labour market reform are regionalisation of control over the labour market policy and the institution of 
arrangements for paid leave. The control reform means that the national labour market council draws up the aims and limits for the local labour market councils, rather than imposing rules-and-regulation control. Cooperation between labour exchange, training institutions and municipalities must be increased, resulting in for instance the drawing up of individual plans of actions on behalf of the unemployed. In addition, arrangements are made to take paid leave for training, child care, and sabbaticals. Unemployed are then recruited replacing persons on paid leave. The purpose of the arrangements for paid leave is creating job circulation in real jobs in the ordinary labour market, thereby creating a job-opening element by means of education and job training.

Secondly, the national system of continued vocational training (CVT) aims at keeping the qualifications of the labour force up-to-date, reacting on changes in the labour market. It takes place in a system of labour market courses, consisting of the training of semi-skilled workers, further training of skilled workers and work introduction courses. It covers a wide range of subjects at various levels put in a coherent modular system; these modules can also be used independently. In addition, adults can participate in Open Education training activities.

\section{Regional Level}

At regional level, regional labour market councils - consisting of representatives of the social partners and the state, counties and municipalities - exercise influence on the implementation of guidelines made by the Government, observing developments in the labour market closely. The labour market council receives annually money which is used for training activities, such as the upgrading of employees necessary as a result of new or changed work tasks, upgrading of unemployed aiming at concrete jobs, and job switching plans. Job switching takes place in small and medium sized enterprises that are not able to do without employees while they attend training courses. Therefore, one or more unemployed after a training period - take over the job of the already employed who is joining a vocational training course. Thereby, the unemployed get a training opportunity, while the qualifications of the already employed can be increased. The employment office is both responsible for finding a suitable or qualified long-term unemployed, as well as training the unemployed prior to the switching of jobs.

In addition, training institutions act at the regional level in close cooperation with the regional council and regional companies. The training centres offer training possibilities to the enterprises in the region and to unemployed within different areas.

In conclusion then, at the national as well as the regional level, most initiatives concern continuing vocational training of the labour force.

\section{Enterprise Level}

At enterprise level, corrective actions are aimed at human resource development planning and the purposeful use of continuing vocational training. In order to gain information about the practices of enterprises regarding training and human resource development, a survey has been conducted in the framework of the Skills Shortages Update.

From this survey, it appears that enterprises coping with changes in personnel requirements generally employ both numerical flexibility (hiring-and-firing) as well as functional flexibility (by job-switching and continued vocational training). The development of core parts of the enterprise is ensured by continued vocational training, thus by using functional flexibility. Enterprises minimize thus the risk of skills shortages by creating internally a highly qualified and flexible staff. In addition, the survey showed that 
enterprises spend most time on recruitment of top management and the least time on semi-skilled workers. These differences influence personnel policy, since employees on whom many resources have been spent are not as easily replaced as other employees. In addition, these differences show where skills shortages are expected.

In the year $1992,90 \%$ of the enterprises have had their employees participating in courses. Almost $34 \%$ of these enterprises had spent more on CVT in 1992 than in 1991, which is among other things a result of the fact that CVT agreements have been part of the central agreements. In these collective bargaining agreements, subjects such as leave rights for CVT and planning of CVT in the enterprise are addressed. $44 \%$ of the enterprises found that their need for CVT was fully met, $28 \%$ found that it was largely met, and $20 \%$ found that their need for CVT was not met, the latter indicating skills shortages. However, only ten percent of the enterprises state that the reasons for their needs not having met was that the available courses did not suit the needs of the enterprise; other reasons were lack of time and lack of financial resources.

In addition, it appears that the level of institutionalization of vocational training is positively correlated to the use of CVT. Enterprises with an independent budget entry for continuing vocational training more often used private CVT than enterprises which had not. Only $16 \%$ of the enterprises do not make estimations of their future needs for CVT. Usually, needs are identified through conversations with employees. However, only $60 \%$ assess the results of CVT, which is normally done by asking employees about their opinion about the course.

Finally, another corrective action to be mentioned is the Icebreaker project, which deals with the fact that many small Danish companies face skills shortages at management level; resulting in barriers to stop growing once a size of 20 to 30 employees has been reached. Therefore, a scheme is set up aiming at getting small companies to hire a person with a higher education. This scheme consists of a trainee scheme for persons with a higher education and investigative and supportive efforts in relation to enterprises. The goal is to provide the enterprise with competence in strategically important areas and that the trainee is employed on an ordinary basis when the subsidy period expires. During the trainee period (up to six months) the enterprise receives the maximum unemployment benefit and the enterprise may choose to reward a higher wage than the unemployment benefit. Therefore, the state does not incur any expenses.

\subsection{Anglia (United Kingdom)}

During the 1980s, the Anglia region experienced a considerable growth $(+10.9 \%)$ in local employment. This growth however, varied by sector and by region. Employment in manufacturing declined while employment in services (banking, finance, professional and business services) increased. Since the third quarter of 1990, the onset of national recession, significant job losses and reduced demand for labour have been incurred, concentrated particularly on retailing and consumer goods manufacturing, but also on construction and property services, and on defence manufacturing industries. In 1991, services accounted for $70.3 \%$ of jobs, and manufacturing for only $21.9 \%$. Employment levels have fallen further since then $(-3.8 \%$ in the three East Anglian counties), with a particular heavy concentration of decline in retailing, tourism, construction and other manufacturing. However, the rate of decline has slowed considerably or even stopped since 1992. The economy of Anglia is presently showing some signs of recovery, though the recovery remains very fragile, and in most cases is not causing companies to adopt a policy of expansion. 
region (minus 126,000 persons). About $35 \%$ of this figure are professional, technical and managerial staff who have been made redundant. Although the commercial outlook is improving, the overall impression is that companies are producing more with fewer staff, achieved by the elimination of extraneus labour. Employment forecasts to the year 2001 show that an overall growth in employment opportunities of $+3,8 \%$ is expected for the Anglia region, although this figure may vary between counties.

Unemployment figures in the Anglia region have traditionally been far below the UK average. Since 1990, however, the region's unemployment rate and volume have risen sharply with the recession, increasing from $3.4 \%$ in 1990 to $8.8 \%$ in December 1993 , thereby increasing faster than the UK average. The reasons for this centre on the drastic impact of the recession on South East England property and construction firms, consumer incomes and industries, previously booming service industries, and finally, the closure and redundancies as a consequence of defence restructuring. The counties Essex, Bedfordshire Hertfordshire are worst hit by this rising unemployment. Cambridgeshire and Suffolk on the other hand are likely to see a resumption of the skilled labour shortages.

In the period 1981-1991 Cambridgeshire was Britain's leading county for high-technology employment growth $(+32 \%)$, and Suffolk in second place. Much of this growth has been in small and medium sized research-intensive firms serving specialized international markets. These have been less susceptible to national recession and defense cuts than large scale firms such as in Essex (and Hertfordshire), which is the region's most rapidly declining county for high-technology employment. Therefore, Essex and Hertfordshire face major problems of labour market restructuring and unemployment amongst skilled but specialized workers used to secure employment in large high-technology manufacturing firms, whereas Cambridgeshire and Suffolk face high-technology demand for a number of scientists willing to work in small firms.

During the 1980s, rates of new firm creation were high, especially in Cambridgeshire and Essex. These rates remained high in the early 1990s, but they were accompanied by an even higher rate of business deregistrations in all counties due to the recession, resulting in a net decline in the number of businesses in the region. Again, the lowest rate of net losses occurred in the counties of Hertfordshire and Cambridgeshire. In these areas the role of small and new firms is of particular importance for economic and job growth in the 1990s. This has implications for training and the provision of skills, since small and new firms usually have particular difficulty in providing formal training courses for their staff due to limited resources. This problem is likely to have been aggravated during the recession.

Desk research and the interview programme show that in general skills shortages are limited to five specific categories of personnel such as radio frequency engineers, engineers with a systems analysis capability, marketing specialists, experienced managers and news reporters for radio and television. Otherwise vacancies can be filled with competent staff. This is in sharp contrast to the situation in the summer of 1990, when there was a general shortage of qualified people at all levels and in all categories. The level of skills shortages reported amongst firms is varied. Employers who have become very much aware to the need for a well-trained work force in order to remain competitive, are retraining and upgrading existing staff to meet new requirements or to cover vacancies. These firms report few skills shortages problems.

In many cases the number of management levels has been reduced. There is an emphasis on staff flexibility; staff is required to have additional skills beside their main discipline, thereby allowing for the elimination of extraneus labour. There is no indication that the economic recovery is leading to a large increase the demand for management in the future; rather a steady increase is expected. 
There is an increased awareness among firms of the need for a well trained labour force to be achieved through 'life-long learning' and continuing education. Most firms do some form of regular assessment of their employees with regards to skills necessary to do the job. In almost all cases, the employer provides or funds training to enable employees to rectify skills deficiencies or to acquire new skills considered essential for the job.

There is a pronounced movement towards multi-skilling for employees. Some firms which declared an intention in 1991 of moving towards multi-skilling have instituted training programmes and now have a pool of highly qualified, flexible labour. There is an increased need for a flexible workforce.

Regarding the choice of an external supplier of training, emphasis is placed on quality by all enterprises; costs, available training facilities and reputation of the training provider are considered less important. Training provided by the company's own staff is used widely to orientate new personnel, and to provide training in particular company activities at all levels.

The survey also concentrated on the achieved and desired level of graduates. It was found that there is still a shortage of good students studying engineering and sciences up to University first degree. Also, there are problems in the ability of some science and technical graduates to write concise and relevant reports in good English.

At school level, several companies still report problems in the three R's for people leaving school at 16 . These problems were also reported in 1991; the indications are that though the situation is less acute, there still is room for improvement.

Further, there is a need for increased contacts between industry and schools to improve the student's interests and motivation. Again, the situation has improved since 1991, but deserves further attention. Finally, there is a need for Higher Education Institutions to achieve a better understanding of the needs of industry.

\subsection{Weser-Ems Region (Germany)}

\section{General}

Skill requirements have probably changed since 1990-1991, in particular with regard to new technologies. In the meantime, education and training have caught up with several fields such as data processing.

Only $20.8 \%$ of all companies reported a shortage of adequately trained labour, which is a considerable drop regarding the fact that this number amounted $73 \%$ in the survey of 1991 . It is however important to note that these enterprises are not presently looking for staff due to the recession; rather they expect that if they were looking for staff, they would have hardly any difficulty in finding the necessary staff. The question may be allowed whether these enterprises are aware of the real situation.

In the survey, interviews were held with executives and personnel managers. It appears that the executives more often seem to realize skills as a problem than personnel managers do. However, there can be two explanations for this phenomenon. First, it can be the case that personnel managers have to justify their own job, and therefore are reluctant to admit that there are skills shortages. The second explanation relates to the fact whether there is a personnel manager in a firm is correlated to the size of the firm; larger firms tend to employ a personnel manager whereas smaller firms do not. The finding that personnel managers do not report skills shortages as often as executives can thus reflect the situation 
that larger firms are less affected by skills shortages problems. In the following this hypothesis will be tested.

There seems to be a controversy over the need of certain skills; some employers claim that the higher the hierarchical level, the more difficulty they have in finding adequate staff, whereas others state the opposite. In addition, employers tend to answer questions about skills needs in terms of professions rather than in terms of skills.

There is a need for printers (as a result of technological change), building cleaners, millers and photographers in industries (due to low prestige or low payment), sales personnel and staff with experience in time and job analysis. The need for sales personnel is related to deteriorating attractiveness of the job and the opinion of employers that the skills necessary for this job cannot be acquired through education. Only one company stressed that it was impossible to find suitable staff. This company however was in need of personnel with both commercial and technical skills; thus multi-skilled personnel. The demand for multi-skilled personnel seems to occur at both top-management level and medium level.

The survey also attempted to reveal some cross-relations between for instance the location of the enterprise and the reported skills shortages. In the 1991 survey, reported skills shortages were the lowest in the city of Osnabrück compared to the more rural areas. In the present survey the level of reported skills shortages is comparatively high in the city of Osnabrück. In addition, in the Emsland region, all enterprises reported skills shortages in 1991, whereas this number has dropped to only one sixth.

Another cross-relation involves the industrial sector and reported skills shortages. In all industrial sectors the number of reported skills shortages has decreased. The sharpest decline has taken place in the service sector, the weakest decline in commerce and trade.

The final cross-relation is between the size of the company and the reported skills shortages. About $70 \%$ of companies employing 1 to 50 persons reported skills shortages in 1991. This number has now dropped to $33 \%$. Noticeable is also the change in percentage in the number of reported skills shortages in enterprises of $51-500$ employees. In 1991, $77 \%$ reported skills shortages; in 1994 only $15 \%$ report skills shortages. These changes in the number of reported skills shortages in relation to the size of the company interviewed is illustrated in table 1.

Table 1. Reported skills shortages and size of company*

\begin{tabular}{lllll}
\hline Number of employees & $\begin{array}{l}\text { Percentage of reported skills shortages } \\
1990 \\
\text { (absolute) }\end{array}$ & relative & $\begin{array}{l}1993 \\
\text { (absolute) }\end{array}$ & relative \\
\hline $1-50$ & $(8 / 11)$ & $70 \%$ & $(2 / 6)$ & $33 \%$ \\
$51-500$ & $(27 / 35)$ & $77 \%$ & $(4 / 26)$ & $15 \%$ \\
$>500$ & $(9 / 14)$ & $64 \%$ & $(4 / 16)$ & $25 \%$ \\
\hline
\end{tabular}

* the figures refer to a very small sample only

Training

Institutions for higher education are hardly contacted for employee training, and therefore still play a minor role in 1994 in continued education and training. Whereas in other countries such as the UK and France, universities of all types provide training for all professional levels, respective courses seem to be underdeveloped in this region. This is rather typical for the majority of education and training provision. The number of institutions of higher education being involved in apprenticeship training is very low. 
The main training providers for enterprises are professional associations, both in-house and external. Seminars of professional organisations and private suppliers are the most offered courses for management in general. Top management training is done through seminars by professional organisations, external agencies and in-house courses. Middle and lower management rely on private training providers and seminars of professional bodies, and in addition on external training and in-house training. Internal training is usually done by on-the-job training, though professional bodies, private training suppliers, external agencies and suppliers also offer such opportunities. More or less the same opportunities are used in training sales staff, other white collar workers and employees who have received academic education before entering industry.

Since the interviewees usually included the costs of apprenticeship training in the amount spent on training, it was not possible to compute an internationally comparable figure regarding training costs, relating to the training of skilled labour only. Therefore, the following figures represent the total cost of education and training. Some $30 \%$ of the companies spend between $0.75 \%$ and $1 \%$ of the total personnel costs on education and training (including the costs for apprenticeships); $5 \%$ has a higher budget. The majority of companies, however, spend less than $0.75 \%$ on eduction and training; $13 \%$ even has no budget at all.

The survey has attempted to test the hypothesis that SMEs in particular in services do not spend money on education and training. This hypothesis could not be confirmed. However, taking the small number of enterprises involved into account, a further conclusion does not seem to be adequate.

In choosing which training institution is to be used, priority is put on quality by $57 \%$ of the enterprises. The second priority is "experience". Third criterion is the "industry specific orientation". Costs is only marked as the fourth important criterion.

\section{The apprenticeship system}

The apprenticeship system is a specific characteristic of the German labour training system. It is regarded as the basis for an adequately qualified staff. Employers however, are worried about the attitudes of apprentices, who seem to lack interest in the job, lack mobility and seem to be lethargic and not active. Overall, the German apprenticeship system is still regarded as being effective.

\section{Education and training}

Enterprises stress the need of life-long learning, particularly in times of change. The emphasis of continued education and training should be on both management as well as technical training. In hardly any enterprise a plan exists according to which training of staff is scheduled. Training opportunities only seem to be offered in times of need.

Enterprises favour external training suppliers if they have specialised in their needs. However, if the training market does not provide an adequate opportunity for specialised training, enterprises are forced to offer in-house courses.

Problems that are encountered in offering employees training opportunities relate to the sometimes hostile reactions of employees. These employees assume either that the training is offered because they 
are not capable for the job, or become anxious thinking they have to meet higher standards after the training or simply feel that they do not need the training offered.

\section{Human Resource Planning}

A substantial human resource plan is hardly ever devised in any of the companies interviewed. Human resource planning is very short term oriented. Presently, employers are concerned about legal initiatives to foster more flexibility in terms of labour, e.g. flexible working hours, contracts of employment.

\subsection{Mid-West of Ireland}

\section{General}

The survey of Update covered 51 enterprise in eleven sectors, ranging in size from 14 to 6500 employees (see chapter 4; Methodology). More than half of the responding companies have increased their workforce, $11 \%$ remained stable and $37 \%$ decreased their workforce (which was fairly accurately predicted by enterprises in the 1991 survey). The reduction in number of employees is due to mechanisation, increased efficiency and company cutbacks due to the recession.

Skills shortages in recruiting new personnel are reported by $57 \%$ of companies; about $30 \%$ found skills deficiencies in their present workforce. These deficiencies - both in new and existing staff - are most predominant in professional/engineer/technical personnel and secondly in (semi-)skilled workers. A number of firms avoided the problem by a policy/practice of job mobility and promotion within the company.

There is an overall reduction in reported shortages of skilled workforce due to the recession and incompany mobility. First, the recession has caused redundancies creating pools of skilled labour who are suitably skilled and available for re-employment. Further, reduced production has lessened the demand for / lack of skilled people. Finally, lay-offs has meant that there are more candidates competing for fewer jobs.

There are low turn-overs of staff due to the recession (lack of alternative employment and causing a desire for job security) and the stable nature of companies. Further, unemployment and the threat of unemployment has reduced the problem of retaining personnel.

Persistent skills shortages in a small number of industrial sectors are due to company-specific skill requirements, competition from overseas offering more attractive salaries, and failure to address longstanding skills problems.

About $43 \%$ of the firms in the survey have structured training policies. In spite of the recession, $60 \%$ claims to have raised or plan to rise training budgets (fairly equal to the 1991 expectation to increase training budgets), while only $10 \%$ decreases its training budget. A very rough estimate of the average training budget amounts up to 59,000 ecu per year, though not many respondents were able to give exact figures.

The most usual means of training is the use of in-company or on-the-job training; over $60 \%$ of (semi-)skilled workers' training and $40 \%$ of training at technical/supervisory level was in-situ. Management/professional level were as likely to be trained at third level, via the private sector or in-company. Further, multi-skilling as essential for maximizing efficiency and reducing skills shortages, appears to be 
at the increase; a deficiency highlighted in the previous survey is now practised in $29 \%$ of companies.

\section{Specific Skills Shortages}

Although in some areas skills shortages were reported in most sectors, they tended to be due to company-specific needs and/or involve relatively small numbers. In addition, the small size of the region makes the region sensitive to market fluctuations rapidly causing redundancies or temporary skills shortages.

The most serious persistent skills shortages, identified as problematic in the 1991 survey, mainly affect the construction, electronics, engineering and services (air craft maintenance) sectors. The difficulties (in all but construction) are in both obtaining and particularly in retaining personnel with certain skills.

The electronics sector reports a continuing shortage of test-technicians, partly due to a relatively small regional pool and partly due to the frequent loss of experienced technical personnel to overseas companies due to lower taxation and higher remuneration overseas. The aircraft maintenance sector also reports a serious, persistent lack of properly licensed and experienced technical personnel. The reason for this is the same as in the electronics sector; experienced people are attracted to either local competitors or to jobs overseas. In this sector, the shortages are aggravated by the expense of training, which is undertaken at the company's risk since once qualified, no legislation exists to bind the qualificant to it. Finally, a potential skills deficit threatens the construction sector, where an upturn in the business will reveal shortages in traditional building trades. This problem has remained since the 1991 survey and reflects the lack of a cohesive training policy or adequate forward planning by the industry and its training providers.

\subsection{Campania (Italy)}

\section{Engineering}

The principle productive areas in Campania are related to the aeronautics component, electronics and mechanics; telecommunications are developing as a consequence of a good investment policy. Particularly these high-technology companies have a need for qualified engineers and specialized personnel, partly due to lack of adequate vocational training courses $(27 \%)$ and partly due to bad school functioning (18\%). About $64 \%$ of the enterprises have invested in training for their own personnel. As a result of the recession, only $38 \%$ plan on investing in training in the short run. Training was provided both internally and externally and was addressed to workers and middle management.

Rather than a shortage of engineers, there is now a lack of specialized technicians. The lack of qualified workers whose professional competence is not provided in school or by vocational training, is still the same. Further, there is a lack of managers able to manage and monitor an enterprise in a difficult time like an economic recession.

\section{Agrofood}

The agrofood sector is one of the leading sectors of Campania, producing pasta and agrofood preserve. Recently, export has increased to European, Japanese and North-American markets. Since agrofood enterprises used seasonal workers, there is always a lack of specialized labour $(75 \%) .58 \%$ of the companies realized training activity for their employees, which is a high number regarding the fact that about $70 \%$ of the enterprises have had a reduction in personnel. Mostly continuing training (68\%) was 
$-21-$

aimed at technological and production areas for workers (35\%) and at language training for clerks (37\%). About $75 \%$ of the companies did not plan on increasing training activities due to the economic situation.

Leather and Tanning

Nearly half of the enterprises increased the internal staff in relation to innovation technology investment. Only $12 \%$ of the enterprises realized a vocational training action, mostly in marketing areas and foreign areas.

This sector is currently growing as a result of export increases. Skills shortages have decreased in the area of specialist workers and technicians. However, there will be a lack of managers and export managers due to increased activities of enterprises and the growth of market internationalisation.

\section{Clothes and textile}

This sector is marked by increased competition from the Far East countries. Formal personnel selection is absent is in this sector; recruitment takes place through personal contacts. Only $25 \%$ of the enterprises organized training for their personnel over the last two years. However, growing product and process innovation creates a demand for specialized workers. Managers believe that this lack of specialized personnel will decrease in a short term period.

\section{Tourism}

In 1991 there was no crisis in the highly developed tourist sector. Presently, this is a problem sector because of increased competition and more demanding tourists. No skills shortages were detected in 1991 in this sector. Nowadays, present and expected skills shortages amount up to $71.4 \%$ with regard to specialist personnel.

\section{Building and Construction}

At this time, practically no new buildings are built, rather, old ones are being renovated. Therefore, there is a shift in demand from constructionists towards 'renovationists'. Reported skills shortages in the 'renovationist' sector amounted up to $25 \%$ in 1991 , whereas its current ratio has increased up to $39.2 \%$, and is expected to rise to $36 \%$.

\section{Services}

This sector consists of banks, information technology companies and consultancy societies. There is still an inadequateness of supply, linked to a scarce demand which is not interested in accepting 'external intervention' in all enterprise operations.

$73 \%$ of these companies have set up a training policy in the last two years, covering all areas of enterprise management, both externally and internally provided. $45 \%$ used funds, of which $80 \%$ were European grants.

Skills shortages are growing in high, middle and low management, partly due to company enlargement, partly due to internationalisation of markets. Middle management skills needs will probably be met in the near future. Problems however, remain to be in companies requiring managers who are able to forward the complex market needs and changes. 


\section{SUMMARY}

General findings regarding skills shortages that can be drawn from the foregoing, can roughly be divided into two categories: findings regarding skills shortages, and findings regarding training.

\subsection{Skills shortages}

The overall impression is that both quantitative and qualitative skills shortages have decreased as a result of the recession and increased in-company mobility, although initial data gathered from the questionnaires indicated that skills shortages had increased in practically all countries. However, in-depth face-to-face interviews that followed after the questionnaire revealed that skills shortages had in fact decreased. The recession has caused redundancies creating a pool of skilled labour, lessened the demand for skilled people and increased the number of candidates competing for fewer jobs; thereby decreasing skills shortages. Table 2 gives an indication of the development of unemployment figures in the five regions.

Table 2. Unemployment figures of the regions, in 1990 and 1994

\begin{tabular}{lcc}
\hline & 1990 & Unemployment \\
& & 1994 \\
\hline Greater Copenhagen Area & $10,4 \%$ & $12,6 \%$ \\
Anglia & $3,4 \%$ & $8,8 \%$ \\
Weser Ems & n.a. & $9,8 \%$ \\
Mid-West of Ireland & $16,0 \%$ & $19,0 \%$ \\
Campania & $21,5 \%$ & $23,0 \%$ \\
\hline
\end{tabular}

Quantitative skills shortages have decreased, particularly because the recession has created large pools of qualified people. If quantitative skills shortages were reported, they were mostly due to specific company demands. Reported quantitative skills shortages varied to a large extent among the five regions, ranging from nurses in the Greater Copenhagen Area to radio frequency engineers in the Anglia region.

Qualitative skills shortages are mainly manifested in the need for multi-skilled personnel aimed at flexibilizing the workforce, as was reported in practically all regions. There is a need for workers combining technical and managerial skills, and there is an emphasis on staff flexibility, meaning that staff is required to have additional skills beside their main discipline. Lack of managerial skills is also reported. Further, some enterprises complained about the lack of interested and motivated personnel. Finally, enterprises state that the "3 R's" of school leavers at 16 need to be improved.

\subsection{Training}

Generally, there is much awareness of the importance of training among the enterprises in order to remain competitive; most enterprises engage in training activities. Training is used to create a highly qualified staff. Company engagement in training varies among the regions, ranging from $90 \%$ of the companies in the Greater Copenhagen Area, to $12 \%$ in the leather tanning sector in Campania, Italy.

Future actions regarding the raise or reduction of training budgets also varies among the regions. In Ireland $60 \%$ of the enterprises increased or plan to increase their budgets on training. In Campania, however, many firms plan on reducing the amount of money spent on training, a development which is 
due to recession. Finally, the level of institutionalization of training appears to be positively related to the use of continued vocational training.

In the choice of an external training provider, quality of the training appears to be the most important criterion, followed by experience; training costs only come in fourth. The satisfaction with the training provided varies among the regions; in The Greater Copenhagen Area, $72 \%$ of the companies is partly or fully satisfied with the training offered; while the overall impression in Campania is that the educational system and vocational training are insufficient and unable to create qualified personnel.

Most firms tend to make estimations for the need of continued vocational training. However, in the Weser Ems region, hardly any plan exists according to which training of staff is scheduled. Human resource planning seems to be short term oriented in this region. The results of continued vocational training are assessed by a relatively small number of the enterprises, usually by asking the employee about his or her opinion about the training course. 


\section{DISCUSSION AND GENERAL RECOMMENDATIONS}

The conclusions drawn in the previous chapter indicate that the reported skills shortages have decreased since the last survey of 1990-1991. However, the question may be raised whether the reported skills shortages reflect the real situation on the labour market. Tracking down skills shortages tends to be a very subjective activity, susceptible to politically based answering of companies, and underestimation or rather the treasuring of skills shortages which are supposed to be signs of a flourishing, dynamic company (the Greater Copenhagen area). In addition, an exclusive methodology of asking companies whether they encounter skills shortages in looking for personnel in times when they do not in fact look for personnel, obviously results in expectation based answers. These answers do not necessarily need to reflect the real situation on the labour market. In fact, in the analysis in the Weser Ems region it is suspected that enterprises are likely to overestimate the skills available in the labour pool.

It thus seems that - at least in some regions - an exclusive methodology of asking enterprises for encountered skills shortages, is slightly biased towards underestimating shortages. It would seem possible, however, that in other regions for instance enterprises would tend to overestimate skills shortages, for example because they expect that a lot of complaining would eventually lead to increased public expenditure on training, from which they would benefit. In this survey, no evidence for the latter was found; however, this was also not the aim of the survey.

Leaving the matter of bias due to the methodology used aside, the survey indicates that the overall level of skills shortages has decreased. The decrease in reported skills shortages - both qualitative and quantitative - is however largely due to the effects of the recession. On the one hand, the recession has created redundancies of skilled people, leading to a general increase in the skills level of the people available for work. On the other hand, the demand for personnel in general has decreased, and therefore as a logical result also the demand for skilled people.

The opinion tends to be that the reported skills shortages have only for a smaller part decreased as a result of increased training activities and/or corrective actions (except for the Greater Copenhagen Area, in which corrective actions have contributed largely to the small amount of skills shortages).

Since the decrease of skills shortages is largely caused by the effects of the recession, the question may be raised what will happen when the economy picks up again. The overall expectation in the regions is that the large pool of skilled labour will quickly be re-absorbed into the workforce, thereby increasing skills shortages, possibly amounting up to the 1991-level.

There is hardly any evidence that enterprises have cut down training budgets on a large scale as a result of the recession. Exception is the region of Campania, in which practically all sectors plan on or already have cut down training budgets in order to save money. This seems a very bad development, especially since this region is already economically fairly weak.

Although then, firms have in general not decreased their training budgets, it seems that most training goes to certain groups of personnel, such as higher management. Therefore, the skills level gap between those with access to training and those excluded from training such as lower level personnel and the long term unemployed increases.

Generally, there is no long term systematic assessment of training activities, except for enterprises in Anglia and Denmark. The results of training are hardly ever assessed in terms of a real cost and benefit analysis. The results of the cost and benefit analysis should however be the basis of a sound human 
capital investment decision.

The most important conclusions that can be drawn from the foregoing, are thus that on the one hand, skills shortages will occur as soon as the expected economic recovery takes place, and on the other hand that only certain groups seem to have benefited from training activities. Therefore, it seems important that increased effort is made to enhance educational and training activities, in particular directed towards groups that have less or no access to training. Emphasis should be on multi-skilling, since this is reported by the majority of firms as an already important or a rapidly becoming important skills profile. In addition, enterprises should be stimulated to involve in training activities as a result of a cost and benefit analysis.

Beside this, analysis of the long term development of skills shortages is essential in designing appropriate training schemes and corrective actions. Since the presently used methodology of interviewing enterprises about their present and expected skills needs possibly provides biased results, there is a need for a more objective skills monitoring instrument. This will be described in the following chapter. 


\section{MONITORING SKILLS SHORTAGES IN THE FUTURE: THE SKILLS BARO- METER}

\subsection{Introduction}

The mismatch between education and the labour market, and more specific the problem of skills shortages has in recent years gained a prominent place on the public policy agenda. Skills shortages are "hampering growth possibilities ...(and) could become so severe that they significantly decrease Europe's competitive position". ${ }^{2}$ Therefore, "the education and training issues related to industrial competence and competitiveness have an overriding importance in relation to the future well-being of Europe and its citizens" $^{3}$

The Skills Shortages Project has in its first phases contributed significantly to the knowledge and understanding of skills needs and the related training requirements in the EU. ${ }^{4}$ It has been demonstrated that, despite regional differences, many skills needs clearly are related to global changes in industrial structure and technological developments. In this respect, some of the challenges which the regions face are quite similar.

The present update shows that skills shortages change over time, not only quantitatively, but also qualitatively. Even in the short period between the 1991 survey and the present one, drastic changes in the skills shortages have taken place. This increases the need for a constant monitoring of skills needs.

In our view the Skills Shortages Project should therefore continue to monitor skills needs on a regular basis. The aim of this monitoring should be:

- to assess quantitative and qualitative skills shortages

- to identify changes in skills shortages over time

- to identify similarities and differences in skills shortages between regions and sectors of industry.

In monitoring economic activities, one typically makes use of specific indicators, like productivity rates, profit rates, stock market price indices (e.g. Dow Jones) et cetera. These indicators serve as a barometer of the economy. They form the basis for further in-depth analysis and are directly used as key indicators for economic policy. Surprisingly, there are hardly any indicators that refer to people's skills and skills needs, although human resources are generally regarded as essential for industrial growth and competitiveness.

We therefore propose to design a Skills Barometer, i.e. an instrument which assesses both quantitative and qualitative skills shortages. The purpose of this barometer is to highlight present skills shortages. This monitoring can give rise to further in-depth analysis in order to formulate specific corrective actions. Moreover, analysing trends in skills shortages may improve our understanding of the future skills needs.

In the design of this monitoring instrument one has to deal with at least the following issues.

2. IRDAC (1990), Skills Shortages in Europe, pp. 16, 20.

3. Ibid, pp. v.

4. See TARGET (1991), EC Skills Shortages Project 1990/1991. Final Synthesis Report. See also T. Casey (1992), Supply/Demand Interfaces in Education \& Training in the Regions of the European Community, Dublin. 


\subsection{Measuring skills shortages}

The first issue relates to the measurement of skills shortages. The present update revealed some serious problems in this regard. In the project, skills shortages were identified by asking the enterprises in the survey whether or not they experienced any skills shortages. It turned out that the direct answers to these questions were not very reliable. Only after asking further, the experienced skills shortages could be rated in a more reliable way.

Measuring skills shortages poses a problem which in itself is not different from measuring other theoretical concepts in social science research. That is, unlike e.g. profit rates or staff turnover, most concepts cannot be measured in a direct way. For these concepts one has to design a measurement instrument. To give a comparison: one does not measure someone's managerial skills simply by asking: "Do you consider yourself a good manager?". The same applies for the measurement of skills shortages. Simply asking whether or not an enterprise experiences skills shortages, is neither a reliable nor a valid way to assess skills needs. As skills shortages cannot be measured in a direct way, one has to make use of a measurement instrument.

In our view it is possible to design an instrument for measuring skills shortages that is both valid and reliable. Such an instrument consists of a series of questions which taken together rate the severeness of skills shortages. These questions should e.g. relate to the effect that skills shortages have on productivity, innovation, growth or competitiveness. The underlying idea is that assessing skills shortages as such seems meaningless, unless it is directly related to an organisation's functioning. To give an example, a shortage of catering personnel may be a nuisance, but will not severely affect a company's functioning. A shortage of engineers however may seriously hamper the company's growth potential.

In a pre-study this measurement instrument should be developed and thoroughly tested. Modern scaling techniques can be used to decide which items should constitute the instrument. A well balanced instrument probably need not contain more than 15-20 questions to constitute a reliable instrument.

This does not mean that this instrument can literally be translated to the different regional contexts. In this respect, there is a difference between formal and functional equivalence. Translating an instrument literally may produce a formal equivalence, but in the translation the concept may get a different meaning and connotation. What one needs in international comparative research is a functional equivalence. By this we mean that the translated instrument has to refer to the same latent concept, but may differ in its manifest expression. This means that much effort has to be put in the translation of the instrument into the different languages by discussing the underlying concepts.

\subsection{Cross-sectional or panel design?}

One of the Skills Barometer's objectives is to measure change. This means, rather than to give a representative picture of the skills shortages in enterprises across Western Europe, its purpose is to identify change as well as to capture major differences in skills shortages between sectors and between regions.

To measure change, a well designed panel study is to be preferred above a cross-sectional design. In the latter case one cannot be sure whether any changes in time reflect real changes or merely differences between the samples.

Although the panel study is the most powerful design to study changes, it has a major drawback: the so- 
called panel mortality. This refers to the non-response in subsequent flows of data collection. If this nonresponse is very high and selective (when e.g. only the flourishing companies respond), this panel mortality can pose a serious problem.

In this respect the experience with the last update was very re-assuring. Most companies were more than willing to participate again in the project, with response rates between 65 and $80 \%$. This must partly be attributed to the efforts that the regional institutions involved have put in building a solid relation with the enterprises in their region. This strategy clearly pays off. It would therefore be wise to use the existing network of regions to do the data collection.

Although a response rate of $70 \%$ can be considered as very high, a panel mortality of $30 \%$ in each flow of data collection will nevertheless soon result in a very small sample. Therefore it should be recommended to replace non-responding enterprises by other enterprises with similar characteristics in order to keep the total sample size intact. The analysis on change could then be restricted to those enterprises which participated in both rounds of data collection.

\subsection{Sample design}

The monitoring with the Skills Barometer need not involve all 26 regions of the first phases in the Skills Shortages Project. The regional dimension can easily be grasped with a limited number of strategically chosen regions. Relevant selection criteria in this respect are: economic situation and industrial structure. The regions which participated in the present update already show a balanced dispersion acording to these criteria, although the southern regions are somewhat underrepresented.

In each region a sample of some 50 companies or organisations should be included in the survey. For a large part, say $75 \%$, this sample is to be drawn according to specific guidelines. These sample criteria involve sector of economic activity and number of employees. Because of the small numbers involved it will be better to concentrate on a few 'key sectors' rather than trying to cover the whole range. The other $25 \%$ should be used to cover the specific regional 'flavour': this means that they should be used to cover those sectors which are of specific interest for this region. If possible, the regional samples should include companies which already participated in the former surveys, as long as they fit in with the selection criteria.

In later updates, the same companies should be approached. Of course, a part of these companies may not exist anymore or may refuse to cooperate. In that case, a company with similar characteristics will have to take its place. Only the $25 \%$ region-specific sample should be allowed to vary over the years, in order to cover dynamics in the regional industrial structure.

\subsection{Data collection}

The last issue to be adressed is the way the data should be collected. This depends largely on the instrument in question. In our view the Skills Barometer should be a highly structured instrument. This makes it possible to use telephone interviews instead of face-to-face interviews. The region of Mid-West Ireland has shown in the present update that telephone interviewing is a cost-effective way to collect data. The response rates are high and the information is of high quality as long as a highly structured instrument is used.

Using a well designed measurement instrument can also solve the problem of who is to be interviewed. Analysis in the Weser-Ems region showed that there is a difference in the responses between executives 
$-29-$

and personnel managers. However, by objectifying the questions as much as possible, one can make the instrument less susceptible for the person to be interviewed. 


\section{APPENDIX: PARTICIPATING REGIONS}

The Greater Copenhagen Area:

"Skills Shortages in the Greater Copenhagen Area? Update"

Ms Birgit Hjermov

Danish Technological Institute

Gregersensvej

DK-2630 Taastrup

DENMARK

Anglia Region:

"A Study of Skills Shortages and Training Needs (1994) in the Anglia Region of the United Kingdom" Mr John U. Shearn

Artiste Limited

PO Box 332

UK Cambridge CB2 1BD

UNITED KINGDOM

Weser-Ems Region:

"Skills Shortages in Europe - An Update of the 1990/91 Skills Analysis in the Region WESER-EMS, D" Mr Volker Gehmlich

Comett Partnershaft W.E.R.

FHS Osnabrück

Albrechtstrasse 30

D-49076 Osnabruck

GERMANY

Mid-West of Ireland:

"Update of the Skills Shortages Project"

Ms Freda Mishan, Mr Tim Hall

European Liason Centre

Plassey Technological Park

Limerick

IRELAND

Campania:

"Skill Needs and Shortages in the Region of Campania, Updated Survey 1994"

Ms Mariella Leone

Comett Tec Train

Centro Direzionale Isolato F12

I-80143 Napoli

ITALY 